\title{
THE OPPORTUNITIES AND CHALLENGES HALAL TOURISM IN BANDUNG-INDONESIA REGENCY
}

\author{
Muhamad Parhan ${ }^{1}$, Mohammad Rindu Fajar Islamy ${ }^{2}$, Nurti Budiyanti ${ }^{3}$, \\ Risris Hari Nugraha ${ }^{4}$, Ganjar Eka Subakti ${ }^{5}$, Ahmad Fuaddin ${ }^{6}$ \\ Email: parhan.muhamad@upi.edu', fajarislam2000@upi.edu²,nurtibudiyanti@upi.edu², \\ risrisharinugraha@upi.edu ${ }^{4}$,ganjarekasubakti@upi.edu ${ }^{5}$, ahmadfuadin@upi.edu ${ }^{6}$ \\ ${ }_{1,2,3,4,5,6}$ Departemen Pendidikan Umum, Universitas Pendidikan Indonesia
}

\begin{abstract}
A new phenomenon that is developing in the world of tourism is halal tourism. Halal tourism is tourism which in its implementation refers to the Islamic law, both in terms of accommodation, attractions, facilities, services and the tourist attractions it self. In Bandung regency, halal tourism is not well known and is still in the preparation stage of development, so that attention and concern for halal tourism in this regency has not yet been developed. Bandung regency Government is in the process of making policies related to the concept of halal tourism. The purpose of this study is to analyze the opportunities and challenges of halal tourism development in Bandung regency and its impact on tourist arrivals to Bandung regency. The research method used in this research is descriptive analysis method. Research data were collected using interview techniques, observation of events in the community and literature studies. The results of this study illustrate that Bandung Regency has a great opportunity in applying the concept of halal tourism because the majority of residents and tourists are Muslim, while the challenges need to be synergized with the policies of a leader, manager and various elements of the community to support Islamic accommodation, attractions, facilities and services .
\end{abstract}

\begin{abstract}
Abstrak: Fenomena baru yang berkembang dalam dunia pariwisata ialah wisata halal. Wisata Halal merupakan wisata yang pada pelaksanaannya mengacu pada syariat Islam, baik akomodasi, atraksi, fasilitas, pelayanan, dan objek wisata itu sendiri. Di Kabupaten Bandung, wisata halal belum banyak dikenal dan masih pada tahap persiapan pengembangan, sehingga perhatian dan kepedulian terhadap wisata halal di kabupaten ini masih belum terbangun. Pemerintah Kabupaten Bandung sedang dalam proses pembuatan kebijakan terkait konsep wisata halal. Tujuan dari penelitian ini adalah untuk menganalisis peluang dan tantangan dari pengembangan pariwisata halal di Kabupaten Bandung serta dampaknya terhadap kedatangan wisatawan ke Kabupaten Bandung. Metode penelitian yang digunakan dalam penelitian ini merupakan metode analisis deskriptif. Data penelitian dikumpulkan dengan menggunakan teknik wawancara, observasi kejadian di masyarakat dan studi literatur. Hasil penelitian ini menggambarkan bahwa Kabupaten Bandung memiliki peluang yang besar dalam menerapkan konsep wisata halal kerana moyoritas penduduk dan wisatawan beragama Islam, adapun tantangan nya perlu ada sinergi kebijakan seorang pemimpin, pengelola serta berbagai elemen masyarakat untuk mendukung akomodasi, atraksi, fasilitas serta pelayanan yang Islami.
\end{abstract}

Kata kunci: islam, pariwisata, pariwisata halal, kabupaten bandung. 


\section{INTRODUCTION}

Tourism is one of the industrial sectors that is currently developing very rapidly throughout the world (Chookaew et al., 2015) and tourism also has a contribution to improving a country's economy. Tourism is a study and activity that leads to practical fulfillment of the economy. In it, many objects can be worked on following interests and are always related, so that tourism becomes a transdisciplinary study. Tourism according to UNWTO (in Suryadana and Octaviany, 2015) is defined as a travel activity and the domicile of a person outside of their residence and environment for more than one consecutive day for travel, business or other destinations without working in the place visited. The above understanding then increasingly developed, because of the breadth of studies and the interrelation of human activities in the tourism business. It also impacts on the emergence of several concepts in tourism because of their contact with economic, socio-cultural, and religious dynamics.

The intersection of the tourism business with religious life then gave rise to a new paradigm in the world of tourism, namely the term halal tourism or halal tourism. The concept of travel is then synonymous with trips made by Muslims in the world. This is related to the prediction of an increase in the Muslim population in the world in 2030 reaching $26.5 \%$. According to Battor and Ismail (2016), halal tourism is all tourism objects or tourism activities that are allowed according to the teachings of Islam to be used by Muslim tourists in the tourism industry. Thus, the status of a Muslim country that is attached to Indonesia has enormous potential to develop the concept of Islam into the world of tourism.

In the concept of halal tourism, all services must refer to the rules that apply to the teachings of Islam. However, this does not make this type of tourism inclusive and has strict limits and is detrimental to non-Muslim tourists. Thus, halal tourism can still be enjoyed together, both Muslim and non-Muslim. This halal tourism is used as a soft power to attract Muslim tourist visits (Kusumaningrum et al., 2017). In general, the concept of halal tourism actually adds to the sense of comfort and security for tourists, because the Islamic rules incorporated into the service system actually make it even better. According to Ferdiansyah (2020), the development of halal tourism in
Indonesia can apply elements of developing family-friendly destinations, services, and facilities that are Muslim-friendly, and Halalconscious.

Halal tourism is a program from the Ministry of Tourism. The halal tourism industry is reviewed based on halal-related industries (Pratiwi et al., 2018). Indonesia synergizes with many parties to develop halal tourism, for example, the Ministry of Tourism in collaboration with the National Sharia Council (DSN), the Indonesian Ulema Council (MUI) and the Business Certification Institute (LSU). A concrete form of cooperation is to develop tourism and promote cultural and religious values which will then be described in the Minister of Tourism and Creative Economy Regulation (Jaelani, 2017).

Bandung Regency meets the criteria as a tourist destination location to contribute to foreign exchange. But to maximize it, many things must still be developed. Many attractions and amenities one of them is in the form of nomadic tourism in Bandung Regency, this has become an interesting thing for tourists to come. The Ministry of Tourism has given awards to the Government of Bandung Regency as the leading halal tourism destination at the Wonderfull Indonesia Halal Tourism Meeting and Conference \& Awarding Indonesia Muslim Travel Index (IMTI) 2019. At the awarding ceremony, there were 16 regencys/cities stating their commitment, to jointly developing halal tourism. The commitment was marked by the signing of a memorandum of understanding $(\mathrm{MoU})$ for 16 regional heads with the Ministry of Tourism. Following up on this, the Bandung Regency Government plans to design actions for Halal Tourism 2019-2025. The draft will be written in the form of academic manuscripts and the draft Regional Regulation (Raperda). Thus, the analysis of opportunities and challenges becomes important for the sustainability of the concept of Islam in the world of tourism.

\section{METHOD}

This research uses descriptive analysis method. With this method, the researcher collected data from observations in the field. Research data were collected using incident observations related to opportunities and challenges in the community and literature studies. From the research data that has been 
obtained then the writer will analyze and finally be able to provide results and conclusions.

\section{RESULT AND DISCUSSION The Concept Of Halal Tourism In Islam}

Halal tourism exists to meet the needs of Muslim tourists according to the teachings of Islam namely the Koran and the Hadith (Parhan, et. al., 2020), bearing in mind that every Muslim is instructed to travel on the Hajj and Umrah pilgrimage (El-Gohary, 2016, pp. 124-130). As in the Koran contained in Qs. AliImran verse 147, Qs. Al-An'am verse 11, Qs. Al-Nahl verse 36, Qs. Al-Naml verse 69, Qs. Al-Ankabut verse 20, Qs. Ar-Rum verses 9 and 42, Qs. Saba verse 18, Qs. Yusuf verse 109, Qs. Al-Hajj verse 46, Qs. Fathir verse 44, Qs. Ghafir verses 82 and 21, Qs. Muhammad verse 10, Qs. Jonah verse 22, Qs. Al-Mulk verse 15. These various verses support the journey of a Muslim with spiritual, physical, and social goals (Zamani-Farahani and Henderson, 2010). The wisdom that we will gain in making the trip is by increasing the inherent sense of faith to always glorify God. So that Islam has a great influence as a religion that rahmatan lil 'aalaamiin (Parhan, et al., 2020);(Budiyanti et al., 2016).

Religion leads to individual awareness as well as collective awareness to always improve spiritually (Olya \& Al-ansi, 2018) which then fosters a motivation to learn and prove the greatness of the religion. In the context of Islam, Islam does not forbid someone to travel, it's just that the intention in traveling must be directed to worship activities. Lots of realities that occur illustrate that the world of tourism has not been accepted in Islam, so many rules that violate Islam. Therefore the concept of halal tourism must be re-developed throughout the world, in order to create a safe, peaceful, peaceful, and healthy life. One interpretation is that Islam accepts tourism because of the pillars of the Hajj which require Muslims to travel to Saudi Arabia to perform the pilgrimage. Tourism that is recommended by Islam is tourism that supports Islam and the faith of someone who travels, such as visiting pilgrimages or visiting Islamic historical buildings or visiting God's creations such as nature. Islam's view of tourism itself depends on how one sees it too because behind all the goodness of tourism there are still many things that do not go hand in hand with Islamic principles.
The word halal comes from the Arabic language halla, yahillu, hillan, wahalalan which has the meaning justified or permitted by the sharia law. It has the meaning of something that is permitted or permitted by Allah (AlQhardhawi, 1994 in Satriana \& Faridah, 2018). Halal tourism is the provision of tourism products and services that meet the needs of Muslim tourists after the teachings of Islam (Mohsin et al., 2016). According to Elena Nikolova (in Fahham, 2017) calls Muslim tourists as tourists who are "a little different". According to him, there are four reasons why Muslim tourists are slightly different from tourists in general, namely (1) the need for prayers, (2) halal food, (3) activities that are avoided, and (4) time of traveling.

The concept of halal tourism is the actualization of the Islamic concept of making halal and haram values the main benchmarks. This means that all aspects of tourism activities are inseparable from halal certification which must be a reference for every tourism actor (Chookaew et al., 2015). In the view of Islam, there are some things that need to be considered, namely (1) Making every trip as a worship activity. (2) The tourist destination in Islam is to study science and think. (3) The concept of tourism is developed to always glorify the greatness of God (Jaelani, 2017, p. 5);(Budiyanti, Aziz, \& Palah, 2020).

The main principles and requirements for halal tourism in Islam are to consider the following aspects, namely halal and good food, no alcoholic beverages, no pork products, no discotheques, space restrictions among men and women, entertainment in accordance with Islamic ethics, the existence of worship space facilities, Islamic clothing for staff uniforms, the availability of worship equipment, the direction of Qibla, art that does not depict the human form, the toilet is positioned not facing the Qibla, finance using the sharia system, hotels and tourism companies must follow the principles of zakat in Islam (Satriana and Faridah, 2018, p. 39). Thus, a tour can be called halal tourism if all activities, facilities, actions, and destinations are allowed according to Islamic teachings (Budiyanti, Aziz, \& Erihadiana, 2020). While a tour can be called an Islamic tour if the Muslim tourist trip is accompanied by the intention to seek the pleasure of Allah or to strengthen his faith in addition to taking into account the halal criteria in the tour (Fahham, 2007, p. 69). 


\section{Tourism Potential in Bandung Regency}

Today, many developing countries pay special attention to the tourism industry. This can be seen from the many tourism development programs in their respective countries or the slogans made by each country, for example Malaysia with the slogan "Malaysia Truly Asia". This certainly causes the tourism industry to become more competitive so it is very important to plan tourism to compete with other countries (Faizi Zahari, 2012).

Indonesia is a country that consists of 34 provinces. Bandung Regency is one of the regions in West Java Province that has quite high tourism potential. The tourism sector is one sector that is a source of foreign exchange for the country. Tourism can be expected to be a determinant and catalyst for gradually developing other sectors of development (Yoeti, 2000).

According to Bandung Regency Regulation No. 6 of 2006 concerning Bandung Regency RIPPDA 2006 to 2016, tourist objects and attractions in Bandung Regency consist of ODTW situ (lake), reservoirs/dams, waterfalls, craters, campsites, plantations and agrotourism. Attractions in Bandung Regency are scattered in various sub-regencys in Bandung Regency with a total of 36 tourist attractions. This is confirmed by the data Based on West Java statistical data in 2010 figures, it is noted that the Regency is ranked 6th in the potential of tourist objects and attractions with a total of 34 attractions. Even now it is noted that attractions in Bandung regency become 36 attractions.

Based on the Bandung Regency Regional Spatial Planning Document 20072027, one of the areas that has a special function of tourism activities is the Ciwidey area. The Ciwidey area consists of several regencys, namely Rancabali Regency, Ciwidey Regency, and Pasirjambu Regency. Some tourist objects in the Ciwidey area include, Situ Patengan, Pranatirta Rancabali, Situ Lembang, Cisabuk Waterfall, Cimanggu Nature Park, Walini Hot Spring, Punceling, Ranca Upas, Gunung Tangsi Tourism Park, Sari Alam Park, Kawah Putih, Gunung Padang, Gambung, and the Cibuni Crater.

The development of a tourist area is inseparable from the efforts made through the cooperation of tourism stakeholders, the community, and the government. Marpaung
(2000, in Widyasmi 2012) states that: "Things that need to be considered in the development of a potential tourist attraction must be done research, inventory, and evaluation before tourism facilities are developed. This is important so that the development of existing tourist attractions can be following the desires of potential markets and to determine the appropriate and appropriate development ".

\section{Opportunities and Challenges of Halal Tourism in Bandung-Indonesia Regency}

Indonesia is a country that has a Muslim majority population. According to the Central Statistics Agency in 2010, Muslims in Indonesia was $87.18 \%$, while others were Christians (6.96\%), Catholics (2.91\%,) Hindus (1.69), Buddhists (0.72) and the rest follow other religions (BPS, 2010). In 2020-2060 it is estimated that the Muslim population will increase by $70 \%$. This potential is utilized by Indonesia to continue its efforts to develop halal tourism (Battor et al., 2017), including developing halal tourism in Bandung Regency.

Bandung Regency can be developed as an Islamic, natural or agro-tourism destination, for both local and foreign tourists, because many attractions and amenities include nomadic tourism in Bandung Regency, this makes tourists interested in coming for a tour. Halal tourism destinations in the Bandung Regency are in the south Bandung area, namely Pacira (Pasirjambu, Ciwidey, Rancabali) and the northern Bandung area namely Cileunyi, Cilengkrang, and Cimenyan.

There are several internal factors in the development of Islamic tourism including in terms of strengths owned such as; the diversity of tourist attractions in Bandung regency which has the potential to be developed into nature tourism, the majority of Bandung regency residents are Muslim, the potential of attracting mosques and Islamic boarding schools, Islamic activities, Muslim fashion shopping events and tours, accessibility to Bandung regency and adequate city public infrastructure facilities, and the vision \& mission of the Bandung Regency Government which is Islamic. The existence of halal tourism in Bandung Regency will have an impact on giving a positive image, which expands new markets that can increase tourist visits to Bandung Regency.

The halal tourism development strategies that can be applied in Bandung Regency include, among others, improvements 
in transportation facilities and access to information for tourists' convenience, collecting data on the potential of sharia tourism, then improving destination facilities that have the potential to become sharia tourism destinations. Also, the need to maintain the cleanliness and comfort of mosques in Bandung as a means of compulsory worship needs of Muslim tourists. The next step is to clarify the mechanism and socialization of getting halal certificates for the tourism industry, and intensify promotions through halal expo events, Muslim fashion festivals as a form of socializing the concepts and prospects of sharia tourism to the tourism industry (Hotels, Restaurants, BPW, Spa).

The award as the leading halal tourism destination at Wonderful Indonesia Halal Tourism Meeting and Conference \& Awarding the 2019 Indonesian Muslim Travel Index (IMTI) received by the Bandung Regency Government was also appreciated by halal tourism practitioners from the Middle East who attended Wonderful Indonesia Halal Tourism Meeting and Conference. The practitioners considered that Bandung Regency and Indonesia had enough names in terms of halal tourism in the eyes of the world. So far, Muslim tourists who come to Bandung Regency have obtained facilities in obtaining halal facilities. Starting from food and drinks, places of worship, to places for personal needs such as toilets, but there needs to be synergy between the policies of a leader, manager, and various elements of the community involved to support accommodation, attractions, facilities, and services that are integrally Islamic.

\section{CONCLUSION AND RECOMENDATION Conclusion}

The concept of halal tourism is the actualization of the Islamic concept of making halal and haram values the main benchmarks. Bandung Regency has considerable opportunities in developing halal tourism. There are several internal factors in the development of Islamic tourism including in terms of strengths owned such as; the diversity of tourist attractions in Bandung regency which has the potential to be developed into natural attractions, the majority of Bandung regency residents are Muslim, the potential appeal of Mosques and Islamic Boarding Schools, Islamic activities, Muslim fashion shopping events and tours, accessibility to Bandung regency and adequate city public infrastructure facilities, and the vision \& mission of the Bandung Regency Government which is Islamic.

\section{Recomedation}

Research results recommend to improve transportation facilities and access to information for the convenience of tourists, collect data on sharia tourism potential, then improve destination facilities that have the potential to become sharia tourism destinations, maintain the cleanliness and comfort of mosques in Bandung as a means of worship needs, clarify the mechanism and socialization to obtain halal certificates, as well as the need for synergy between the policies of a leader, manager, and various elements of society involved to support accommodation, attractions, facilities, and services that are integrally Islamic. 


\section{References}

Budiyanti, N., Aziz, A. A., \& Erihadiana, M. (2020). Strategy of Insan Kamil in Building Green Education. International Journal on Advanced Science, Education, and Religion, 3(2), 72-82. https://doi.org/10.33648/ijoaser.v3i2.54

Budiyanti, N., Aziz, As. A., \& Palah. (2020). THE FORMULATION OF THE GOAL OF INSAN KAMIL AS A BASIS FOR THE. IJECA (International Journal of Education and Curriculum Application), $3(2), 1-10$.

Budiyanti, N., Rizal, A. S., \& Sumarna, E. (2016). IMPLIKASI KONSEP ŪLŪL 'ILMI DALAM AL-QUR'ĀN TERHADAP TEORI PENDIDIKAN ISLAM (Studi Analisis Terhadap Sepuluh Tafsīr Mu'tabarah). TARBAWY: Indonesian Journal of Islamic Education. https://doi.org/10.17509/t.v3i1.3459

BAPPEDA Kabupaten Bandung. 2008. Dokumen Rencana: Rencana Tata Ruang Wilayah Kabupaten Bandung 2007-2027. Soreang: BAPPEDA Kabupaten Bandung

Battour, M., \& Ismail, M. N. (2016). Halal tourism: Concepts, practises, challenges and future. In Tourism Management Perspectives. https://doi.org/10.1016/j.tmp.2015.12. 008

Battour, M., Ismail, M. N., Battor, M., \& Awais, M. (2017). Islamic tourism: an empirical examination of travel motivation and satisfaction in Malaysia. Current Issues in Tourism, 20(1), 50-67. https://doi.org/10.1080/13683500.201 4.965665

Chookaew, S., chanin, O., Charatarawat, J., Sriprasert, P., \& Nimpaya, S. (2015). Increasing Halal Tourism Potential at Andaman Gulf in Thailand for Muslim Country. Journal of Economics, Business and Management. https://doi.org/10.7763/joebm.2015.v3 .277

El-Gohary, H. (2016). Halal tourism, is it really Halal? In Tourism Management Perspectives. https://doi.org/10.1016/j.tmp.2015.12. 013
Fahham, A Muchaddam. (2007). Pemahaman Pengasuh Pondok Pesantren Terhadap Hadits-Hadits Misoginis. Egalita, 2(1), 31-47.

Fahham, A. M. (2017). Tantangan Pengembangan Wisata Halal Di Nusa Tenggara Barat. Jurnal MasalahMasalah Sosial, 8(1), 65-79.

Faizi Zahari. 2012. Mengapa Perencanaan Pariwisata itu Penting dalam The Planners ePortfolio. Halam 4. Volume 06- Januari 2012. Bandung: HMP Pangripta Loka ITB.

Ferdiansyah, H. (2020). Pengembangan Pariwisata Halal Di Indonesia Melalui Konsep Development of Halal Tourism in Indonesia Through Smart Tourism Concept. 2(1), 30-34.

Jaelani, A. (2017). Halal Tourism Industry in Indonesia: Potential and Prospects. SSRN Electronic Journal, 76237. https://doi.org/10.2139/ssrn.2899864

Kusumaningrum, D. N., Fairuz, A. M., Putri, E. P., \& Amalia, E. P. (2017). Trend Pariwisata Halal Korea Selatan. Senaspro, 855-865.

Mohsin, A., Ramli, N., \& Alkhulayfi, B. A. (2016). Halal tourism: Emerging opportunities. Tourism Management Perspectives, 19(2016), 137-143. https://doi.org/10.1016/j.tmp.2015.12. 010

Olya, H. G. T., \& Al-ansi, A. (2018). Risk assessment of halal products and services: Implication for tourism industry. Tourism Management, 65, 279-291.

https://doi.org/10.1016/j.tourman.2017 .10 .015

Parhan, M., Islamy, M. R. F., Budiyanti, N., Nugraha, R. H., \& Hyangsewu, P. (2020). Responding to Islamophobia by Internalizing the Value of Islam Rahmatan lil Alamin through Using the Media. Islam Realitas: Journal of Islamic and Social Studies, 6(2), 139152.

Parhan, M., Tieky I. D, A. ., Irma H. S, A. ., Susnita, A. ., \& Fauziah K, E. . (2020). Problematika Penerapan Metodologi Barat pada Pendidikan Dasar dalam Perspektif Islam . AL-ADABIYAH: Jurnal Pendidikan Agama Islam, 1(1), 17-32. Retrieved from https://aladabiyah.iain- 
jember.ac.id/index.php/adabiyah/articl e/view/8

Pratiwi, S. R., Dida, S., \& Sjafirah, N. A. (2018). Strategi Komunikasi dalam Membangun Awareness Wisata Halal di Kota Bandung. Jurnal Kajian Komunikasi, $6(1), \quad 78$. https://doi.org/10.24198/jkk.v6i1.1298 5

Satriana, E. D., \& Faridah, H. D. (2018). Halal Tourism: Development, Chance and Challenge. Journal of Halal Product and Research, 1(2), 32. https://doi.org/10.20473/jhpr.vol.1issue.2.32-43

Widyasmi, Kartika. 2012. Strategi Pengelolaan Pariwisata Bahari di Kecamatan Bayah Kabupaten Lebak. Skripsi. Serang: UNTIRTA

Yoeti, Oka A. 2000. Ekowisata : Pariwisata Berwawasan Lingkungan Hidup. Jakarta: P.T. Pertja

Zamani-Farahani, H., \& Henderson, J. C. (2010). Islamic tourism and managing tourism development in islamic societies: The cases of Iran and Saudi Arabia. International Journal of Tourism Research. https://doi.org/10.1002/jtr.741. 